\title{
Physical-sensory evaluation of a cereal bar with quinoa: a preliminary study
}

\author{
Avaliação físico-sensorial de uma barra de cereais com quinoa: um estudo preliminar
}

\author{
Ana Garcia ${ }^{1}$, Cristina Reis ${ }^{1}$, Joana Serpa ${ }^{1}$, Joana Viegas ${ }^{1}$, Marta Ferreira ${ }^{1}$, Susana Almeida ${ }^{1}$, Maria \\ Cristiana Nunes ${ }^{1,2}$, Nelson Tavares ${ }^{1,3}$ \\ ${ }^{1}$ Escola de Ciências e Tecnologias da Saúde, Universidade Lusófona de Humanidades e Tecnologias, Av. Campo Grande \\ 376, 1749-024 Lisboa, Portugal. \\ ${ }^{2}$ LEAF (Linking Landscape Environment Agriculture and Food) Research Center, Instituto Superior de Agronomia, \\ Universidade de Lisboa, Tapada da Ajuda 1349-017 Lisboa, Portugal. \\ ${ }^{3}$ CBIOS (The Research Center for Biosciences \& Health Technologies),Universidade Lusófona de Humanidades e \\ Tecnologias, Av. Campo Grande 376, 1749-024 Lisboa, Portugal. \\ Email:nelson.tavares@ulusofona.pt
}

\begin{abstract}
The consumption of cereal bars has increased in recentyears because it is a quick and practical way to eat. Cereal bars are products obtained by blending dry ingredients and binder components which complement each other by conferring the sensory properties to the bars. Quinoa is considered a functional food, since in addition to providing basic nutrition, it has attributes with a direct positive effect on health and well-being. This study focuses on the evaluation of white quinoa and red quinoa bars, without added sugar or additives, suitable for use as healthy snacks. The effect of quinoa type and processing conditions on sensory properties of cereal bars was studied. Five different processing methods (baking and/or drying and/or heating) were evaluated. Bars with higher preliminary sensory scores were selected for further evaluation by a consumer panel and instrumental evaluation of texture and color (CIELab) . This work suggests that quinoa is an interesting functional ingredient to develop new cereal bars as an alternative to the conventional commercial products, with desirable physical and sensory proprieties.
\end{abstract}

Keywords: quinoa, cereal bar, texture, colour.

\begin{abstract}
Resumo
O consumo de barras de cereais tem aumentado nos últimos anos devido à sua conveniência, já que são alimentos práticos e fáceis de consumir. As barras de cereais são produtos obtidos pela mistura de ingredientes secos e de aglutinantes, que se completam mutuamente conferindo as características sensoriais às barras. A quinoa é considerada um alimento funcional, já que para além da função nutricional tem também um impacto positivo na saúde humana. Este trabalho tem como objetivo o desenvolvimento de barras de quinoa branca e quinoa vermelha, sem adição de açúcar e aditivos, adequada para a utilização como snack saudável. Estudou-se o efeito do tipo de quinoa e das condições de processamento nas propriedades sensoriais e de textura das barras de cereais. Foram avaliadas cinco diferentes metodologias (cozedura e/ou secagem e/ou aquecimento). Através de uma análise sensorial preliminar foi possível selecionar as barras a submeter à análise de um painel de consumidores e a avaliação instrumental da textura e da cor (CIELab). Este trabalho sugere que a quinoa é um ingrediente funcional interessante para o desenvolvimento de novas barras de cereais como uma alternativa aos produtos comerciais convencionais, com propriedades físicas e sensoriais desejáveis.
\end{abstract}

Palavras-chave: quinoa, barra de cereais, textura, cor. 


\section{Introduction}

Cereal bars can replace snacks that are high in sugars, sodium and/or lipids, and are found in the market under different brands, flavours and nutritional compositions. These products are obtained by blending dry ingredients and binders that taken together impart flavor, texture and physical properties to the bars [1]. The main aspects to take into consideration in the development of these type of products are the choice of cereals, selection of carbohydrates, along with enrichment with various nutrients and their stability during processing. The association between cereal bars and healthy foods is a trend in the food industry, which brings positive results to the market for these products [2].

Quinoa is the common name for Chenopodium quinoa, which originated in the Andean region. It is an herbaceous plant grown as a grain crop primarily for its edible seeds and is considered as a pseudocereal. The Food and Agriculture Organization of the United Nations (FAO) declared 2013 the International Year of Quinoa.

It is known that quinoa has considerable positive effects on metabolic, cardiovascular and gastrointestinal health in humans [3-4]. High variations in nutrient contents of quinoa are observed per $100 \mathrm{~g}$ edible portion on fresh weight basis: protein $(9.1-15.7 \mathrm{~g})$, total fat $(4.0-7.6$ g) and dietary fiber $(8.8-14.1 \mathrm{~g})$ [5]. The main characteristic of this grain is its high protein and essential amino acids content, such as lysine, tryptophan, histidine and valine, which could improve the immune system of patients in several pathologies. Quinoa also contains a high amount of healthy/beneficial phytochemicals including saponins and phytosterols [3]. Betaxanthins and betacyanins can explain the diversity of quinoa colors. Not only color is modulated by The presence of betalains in the grains modulates not only color, however, also the high antioxidant and free radical scavenging activities [6].

The use of quinoa as a functional ingredient in food has been limited to a narrow niche market and the research on food products with quinoa is scarce [7-8].

The ingredients included in cereal bars are usually grains, seeds and fruits. The cereals most used are wheat, corn, oat and rice. Oats are rich in proteins and soluble fiber and their consumption can bring several health benefits [9]. Other ingredients, such as nuts, dehydrated fruits, bananas and honey can also be added to cereal bars in order to optimize the nutritional value and texture of the end product. Nuts are rich in nutrients with a specific lipid profile, especially in oleic and linoleic acid. They also have also a considerable content

\section{Introdução}

As barras de cereais podem substituir os snacks ricos em açúcares, sódio e/ou lípidos, encontrando-se no mercado sob diferentes marcas, sabores e composição nutricional. Estes produtos são obtidos pela mistura de ingredientes secos e aglutinantes que se completam mutuamente conferindo o sabor, textura e propriedades físicas às barras [1]. Os principais aspetos a ter em consideração na elaboração deste tipo de produtos são a escolha dos cereais, seleção dos hidratos de carbono, enriquecimento com vários nutrientes e a sua estabilidade durante o processamento. A associação entre as barras de cereais e os alimentos saudáveis é uma tendência no setor alimentar, o que traz resultados positivos para o mercado destes produtos [2].

Quinoa é o nome vulgar para Chenopodium quinoa, uma planta herbácea da região dos Andes, cultivada pelas suas sementes comestíveis e considerada um pseudocereal. A Organização das Nações Unidas para a Alimentação e Agricultura (FAO) declarou 2013 como $\mathrm{o}$ ano internacional da quinoa.

Sabe-se que a quinoa tem efeitos positivos consideráveis sobre a saúde metabólica, cardiovascular e gastrointestinal em humanos [3-4]. São observadas altas variações nos teores de nutrientes da quinoa por cada $100 \mathrm{~g}$ de porção comestível (peso fresco): proteína $(9,1$ - 15,7 g), gordura total $(4,0-7,6 \mathrm{~g})$ e fibra dietética $(8,8$ - 14,1 g) [5]. A principal característica deste grão é o seu elevado teor em proteína e aminoácidos essenciais, tais como a lisina, triptofano, histidina e valina, que melhoram o sistema imunológico de pacientes com diversas patologias. A quinoa também contém uma grande quantidade de fitoquímicos benéficos para a saúde, incluindo saponinas e fitoesteróis [3]. Betaxantinas e betacianinas explicam a diversidade de cores, mas não apenas a cor é modulada pela presença de betalaínas nos grãos, também a elevada atividades antioxidante [6]. $\mathrm{O}$ uso de quinoa como ingrediente funcional nos alimentos tem sido limitado a um nicho de mercado e a pesquisa sobre produtos alimentícios com quinoa ainda é escassa [7-8]. Os ingredientes incorporados nas barras de cereais são geralmente grãos, sementes e frutos. De entre os cereais os vulgarmente usados são o trigo, milho, aveia e arroz. A aveia é um cereal rico em proteínas e fibras solúveis e o seu consumo pode trazer benefícios para a saúde [9]. Existem ainda outros ingredientes, como nozes, frutos desidratados, bananas e mel, que podem ser adicionados às barras de cereais de forma a otimizar o valor e textura do produto final. A noz apresenta um perfil lipídico rico em ácido oleico e linoleico e possui um conteúdo considerável de fitoes- 
of phytosterols, vitamin E and selenium [9]. The consumption of this type of fruit can improve the symptoms of coronary heart disease and has also been associated with the reduction of the risk of hypertension and diabetes mellitus [10]. Banana is an important source of minerals and vitamins and is composed of $70 \%$ water, $1.2 \%$ protein, $27 \%$ carbohydrates and calcium, iron, iodine, magnesium, cobalt, vitamin A, riboflavin, among other components [11].

The incorporation of functional ingredients in cereal products has serious implications on their structure and therefore there are technological limitations. Studies have been previously made regarding the incorporation of Psyllium fiber in traditional biscuits $[12,13]$ and microalgae in pasta products [14].

This study aims to develop a cereal bar using two types of quinoa, white and red, oatmeal flakes, prunes, raisins, nuts, fresh banana and honey as ingredients, based on a homemade recipe. The impact of two types of quinoa (white and red) on sensory and physical properties was studied as well as different processing conditions using baking and/or drying and/or heating. Selected quinoa bar samples were tested using sensory evaluation by a consumer panel and subjected to texture and colour instrumental evaluation.

\section{Materials and methods}

\section{Preparation of the bars}

All the ingredients, white real quinoa and red quinoa (Cem porcento), oatmeal flakes (Salutem), black prunes (Continente), black raisins (Continente), nuts (Continente), fresh bananas and honey (SerraMel) were purchased in a local market.

The formulation (Table 1) of the quinoa bars was adapted from a homemade recipe. The dry ingredients were crushed in a kitchen grinder and mixed with the binder solution formed by banana and honey (Figures 1 and 2). The use of an electric oven (Tecnoeka Sri KF 912) and/or a drier at $70^{\circ} \mathrm{C}$ was tested according to the flowchart in Figure 1. After mixing, the mass was shaped in two bars with a rectangular form $(10 \mathrm{~cm}$ long $\mathrm{x} 4$ $\mathrm{cm}$ wide $\mathrm{x} 1 \mathrm{~cm}$ high) and different preparation conditions were tested: (i) baking $\left(180^{\circ} \mathrm{C}-25\right.$ minutes), (ii) baking $\left(180^{\circ} \mathrm{C}-25\right.$ minutes) with subsequent drying $\left(70^{\circ} \mathrm{C}-24 \mathrm{~h}\right)$ and (iii) drying at $70^{\circ} \mathrm{C}$ for 24 hours. In alternative, bars were prepared by heating on an electric stove, with or without subsequent drying, as represented in Figure 2. In this case, ingredients were mixed and teróis, vitamina E e selénio [9]. O consumo deste tipo de fruto está associado a benefícios no que diz respeito à doença coronária e parece estar associado à redução do risco de hipertensão e diabetes mellitus [10]. A banana constitui uma fonte importante de minerais e vitaminas e é composta por $70 \%$ de água, $1,2 \%$ de proteína, $27 \%$ de hidratos de carbono, contendo cálcio, ferro, iodo, magnésio, cobalto, vitamina $\mathrm{A}$, riboflavina, entre outros [11].

A incorporação de ingredientes funcionais em produtos alimentares à base de cereais pode ter impacto na estrutura do material, tendo por isso limitações tecnológicas. Anteriormente foram desenvolvidos trabalhos sobre a incorporação de fibra de Psyllium em bolachas $[12,13]$ e microalgas em massas alimentícias [14].

No presente trabalho, pretende-se desenvolver uma barra de cereais, usando como ingredientes dois tipos de quinoa, branca e vermelha, flocos de aveia, ameixas secas e passas de uva, nozes, banana fresca e mel, baseada numa receita caseira. Avaliou-se o impacto do uso de dois tipos de quinoa (branca e vermelha) nas propriedades físicas e sensoriais, assim como o impacto de diferentes condições de processamento, usando a cozedura no forno e/ou secagem e/ou aquecimento. Os produtos selecionados serão submetidos a avaliação por um painel de consumidores e à análise instrumental da textura e da cor.

\section{Materiais e métodos}

\section{Preparação das barras}

Todos os ingredientes, quinoa real branca e quinoa vermelha (Cem porcento), flocos de aveia (Salutem), ameixas pretas desidratadas (Continente), passas de uva preta (Continente), nozes (Continente), bananas frescas e mel (SerraMel) foram adquiridos no comércio local. A formulação das barras de quinoa (Tabela 1) foi adaptada de uma receita caseira. Os ingredientes secos foram misturados com a solução aglutinante formada pela mistura de banana e mel (Figuras 1 e 2).

A utilização do forno elétrico (Tecnoeka Sri KF 912) e/ ou do secador a $70^{\circ} \mathrm{C}$ foi testada conforme o esquematizado na Figura 1. Após a mistura, a massa foi moldada em barras de forma retangular $(10 \mathrm{~cm}$ comprimento $\mathrm{x} 4$ $\mathrm{cm}$ largura $\mathrm{x} 1 \mathrm{~cm}$ altura) e seguidamente foram testadas várias condições de processamento: (i) cozedura $\left(180^{\circ}\right.$ $\mathrm{C}-25 \mathrm{~min})$, (ii) cozedura $\left(180^{\circ} \mathrm{C}-25 \mathrm{~min}\right)$ seguida de secagem $\left(70^{\circ} \mathrm{C}-24 \mathrm{~h}\right)$ e (iii) secagem a $70^{\circ} \mathrm{C}$ durante 24h. Em alternativa, as barras foram preparadas com aquecimento num fogão elétrico, com ou sem secagem posterior, conforme representado na Figura 2. Neste 
heated until reaching a temperature of $70^{\circ} \mathrm{C}$. Thereafter the mixture was molded in a rectangular form and immediately stored at ambient temperature (iv) or dried at $70^{\circ} \mathrm{C}$ for $24 \mathrm{~h}(\mathrm{v})$. In this way, ten distinct samples were produced, five of white quinoa and five of red quinoa, corresponding to the five production methods. After cooling, all the bars were stored in plastic bags at room temperature. caso, os ingredientes foram misturados e aquecidos até atingirem a temperatura de $70^{\circ} \mathrm{C}$. Seguidamente, a mistura foi moldada na forma retangular e armazenada à temperatura ambiente (iv) ou desidratada a $70^{\circ} \mathrm{C}$ durante $24 \mathrm{~h}(\mathrm{v})$. Deste modo, foram produzidas 10 amostras distintas, cinco de quinoa branca e cinco de quinoa vermelha, correspondentes aos cinco métodos de produção. Após o arrefecimento todas as barras foram armazenadas em sacos de plástico à temperatura ambiente.

Table 1/ Tabela 1 - Formulation of quinoa bars (white and red). Formulação das barras de quinoa (branca ou vermelha).

\begin{tabular}{lr}
\hline Ingredients/Ingredients & Quantity/Quantidade \\
\hline $\begin{array}{l}\text { Quinoa } \\
\text { Oatmeal flakes/Flocos de } \\
\text { aveia }\end{array}$ & $72.5 \mathrm{~g}$ \\
$\begin{array}{l}\text { Prunes /Ameixa preta } \\
\text { desidratada }\end{array}$ & $145.0 \mathrm{~g}$ \\
$\begin{array}{l}\text { Black raisins/ Passa de uva } \\
\text { preta }\end{array}$ & $36.3 \mathrm{~g}$ \\
Nuts/ Noz & $96.0 \mathrm{~g}$ \\
Banana & $72.5 \mathrm{~g}$ \\
\hline Honey/Mel & $250.0 \mathrm{~g}$ \\
\hline
\end{tabular}




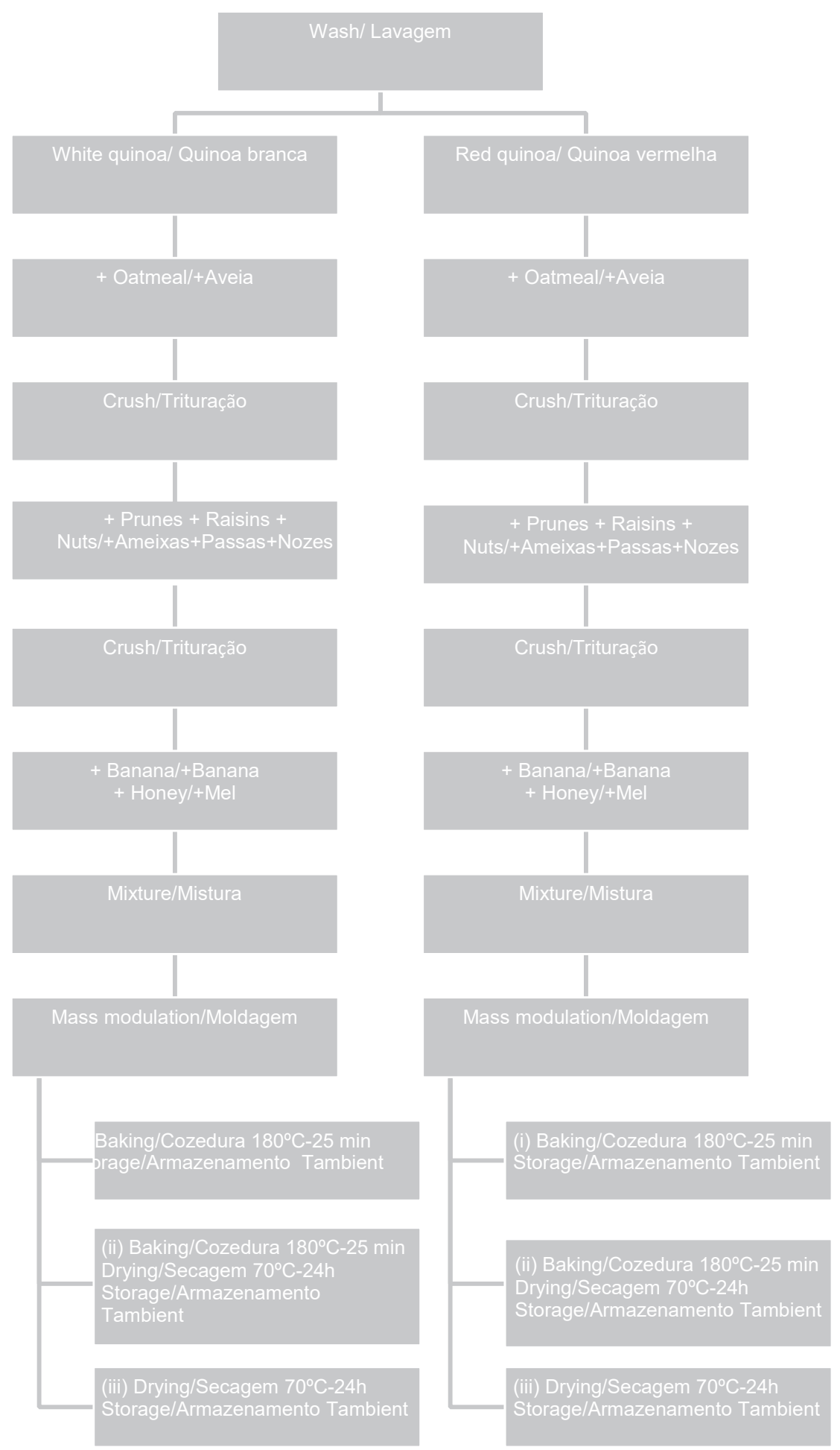

Figure 1/ Figura 1 - Preparation of quinoa bars using baking at $180^{\circ} \mathrm{C}$ and/or drying at $70^{\circ} \mathrm{C}$. Preparação das barras de quinoa usando a cozedura a $180^{\circ} \mathrm{C}$ e/ou secagem a $70^{\circ} \mathrm{C}$ 


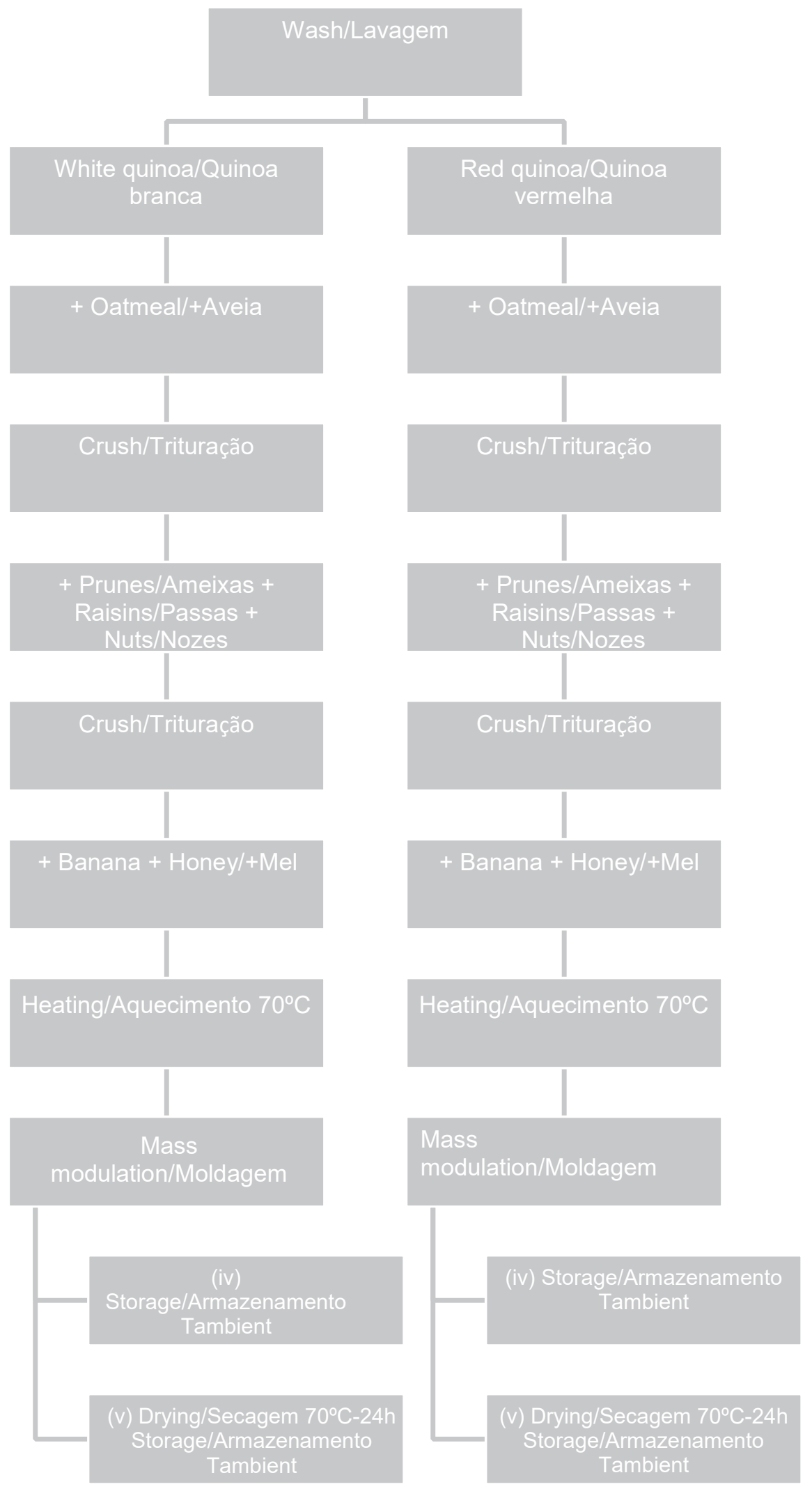

Figure 2/ Figura 2 - Preparation of quinoa bars using heating and/or drying at $70^{\circ} \mathrm{C}$. Preparação das barras de quinoa usando o aquecimento e/ou secagem a $70^{\circ} \mathrm{C}$. 


\section{Sensory evaluation}

A group of 27 potential consumers aged between 19 and 26 years old carried out a preliminary sensorial evaluation of the ten samples produced, having selected three of the quinoa bars, based on texture, colour and taste. These three selected bars - white quinoa bar baked at $180^{\circ} \mathrm{C}$ for 25 minutes (i), white quinoa bar heated at $70^{\circ} \mathrm{C}$ with subsequent drying at $70^{\circ} \mathrm{C}$ for 24 hours (v) and red quinoa bar processed at the same conditions (v), were then subjected to consumer tests. An untrained panel of 43 individuals, mainly composed of university students, tested quinoa bars for the overall impression on a scale with nine assement levels from (1) I disliked it very much, (2) I disliked it a lot, (3) I disliked it, (4) I slightly disliked it, (5) I did not like or dislike, (6) I did not like it very much, (7) I liked it, (8) I liked it a lot, to (9) I liked it very much. In order to verify the differences between the three selected bars, the obtained data were evaluated by the method of analysis of variance (ANOVA) with means comparison by Tukey Test, $(\alpha=0.05)$, using SPSS 21 .

\section{Instrumental analysis of texture}

Texture was measured in a texturometer TA.XT plus (Stable MicroSystems, UK), performing cutting tests using the Craft Knife Blade probe $(1 \mathrm{~mm} / \mathrm{s}$ speed and 5 $\mathrm{mm}$ of penetration).

Firmness was considered as the maximum resistance to the penetration of the probe and was calculated as the height of the force peak in N. Measurements were repeated six times for each sample (three measurements per bar).

\section{Colour analysis}

The colour of quinoa bars samples was measured instrumentally using a Minolta CR-400 (Japan) tristimulus colorimeter with standard illuminant D65 and a visual angle of $2^{\circ}$. The results were expressed in terms of the CIELab uniform colour system [15]. L* corresponds to lightness ranging from $0 \%$ (dark) to $100 \%$ (bright). The chromaticity coordinates $\mathrm{a}^{*}$ and $\mathrm{b}^{*}$ indicate the colour direction, increasing the saturation until \pm 60 from the dull/achromatic center $\left(a^{*}=0, b^{*}=0\right)$ to $+a^{*}$ (red), $-a^{*}$ (green), $+b^{*}$ (yellow) or $-b^{*}$ (blue). The measurements were conducted under the same light conditions, using a white standard $\left(\mathrm{L}^{*}=94.61, \mathrm{a}^{*}=-0.53, \mathrm{~b}^{*}=3.62\right)$ under artificial fluorescent light at room temperature, replicated six times for each formulation sample.
Análise sensorial

Um grupo de 27 potenciais consumidores com idade compreendidas entre 19 e 26 anos fez a avaliação sensorial preliminar das dez amostras de barras de cereais, tendo em consideração a textura, cor e sabor da barras, e selecionou três das barras de quinoa para dar continuidade ao estudo. As barras selecionadas - barra de quinoa branca cozida a $180^{\circ} \mathrm{C}$ durante $25 \mathrm{~min}$ (i), barra de quinoa branca aquecida a $70^{\circ} \mathrm{C}$ e com secagem posterior a $70^{\circ} \mathrm{C}$ durante $24 \mathrm{~h}(\mathrm{v})$ e barra de quinoa vermelha processada nas mesmas condições (v), foram avaliadas por um painel de consumidores. Quarenta e três indivíduos não treinados, na sua maioria estudantes universitários, classificaram as barras de quinoa em termos de impressão global, usando uma escala com 9 níveis, de (1) desgostei muitíssimo, (2) desgostei muito, (3) desgostei, (4) desgostei pouco, (5) não gostei nem desgostei, (6) gostei pouco, (7) gostei, (8) gostei muito, to (9) gostei muitíssimo. Para verificar as diferenças entre as três barras selecionadas, os dados obtidos foram avaliados pelo método de análise de variância (ANOVA) com comparação de médias pelo Teste de Tukey, utilizando o SPSS 21.

\section{Avaliação instrumental da textura}

A textura foi avaliada num texturómetro TA.XTplus (Stable MicroSystems, UK), utilizando testes de corte com a sonda Craft Knife Blade $(1 \mathrm{~mm} / \mathrm{s}$ velocidade e 5 mm de penetração).

Considerou-se a firmeza como a resistência máxima à penetração da sonda, calculada como o pico máximo da força em N. As medições foram repetidas seis vezes para cada amostra (três medidas em cada barra).

\section{Avaliação da cor}

A cor das barras de quinoa foi medida instrumentalmente usando um colorímetro Minolta CR-400 (Japão), munido de um iluminador standard D65 e um ângulo de fase de $2^{\circ}$. Os resultados foram expressos usando o sistema de cor CIELab [15]. L* corresponde à luminosidade, variando de $0 \%$ (escuro) a $100 \%$ (claro). As coordenadas cromáticas a* e b* indicam a direção da cor, aumentando a saturação até \pm 60 desde o centro acromático $\left(\mathrm{a}^{*}=0, \mathrm{~b}^{*}=0\right) \mathrm{a}+\mathrm{a}^{*}$ (vermelho), - $\mathrm{a}^{*}$ (verde), $+b^{*}$ (amarelo) ou $-b^{*}$ (azul). As medições foram conduzidas sob as mesmas condições de luz, usando um padrão branco e luz fluorescente artificial, à temperatura ambiente, e cada amostra foi testada seis vezes. 


\section{Results and discussion}

Figure 3 shows the results for the sensory evaluation of the quinoa bars by a group of 43 consumers. No significant difference between sensory evaluation results between bars was observed. Bick and co-workers [7] studied the substitution of wheat flour for quinoa flour in biscuits. At 10, 20 and 30\% quinoa contents did not obtain great differences in sensory evaluation, although the firmness of the cookies decreased with the increase of quinoa flour. Stikic et al [8] studied the incorporation of quinoa seeds in wheat bread formulations with up $20 \%$ and a positive effect on the rheological behaviour of dough and bread was obtained.

\section{Resultados e discussão}

Na Figura 3 estão apresentados os resultados da avaliação sensorial das barras de quinoa por parte de um grupo de 43 consumidores. Não foram encontradas diferenças estatisticamente significativas na avaliação sensorial entre as três barras.

Bick e colaboradores [7] estudaram a substituição de farinha de trigo por farinha de quinoa em biscoitos. Para teores de 10, 20 e 30\% de quinoa não obtiveram grandes diferenças na avaliação sensorial, embora a firmeza dos biscoitos tenha diminuído com o aumento da farinha de quinoa. Stikic et al [8] estudaram a incorporação de sementes de quinoa em formulações de pão de trigo e obtiveram um efeito positivo no comportamento reológico das massas e dos pães para teores de $20 \%$ de quinoa.

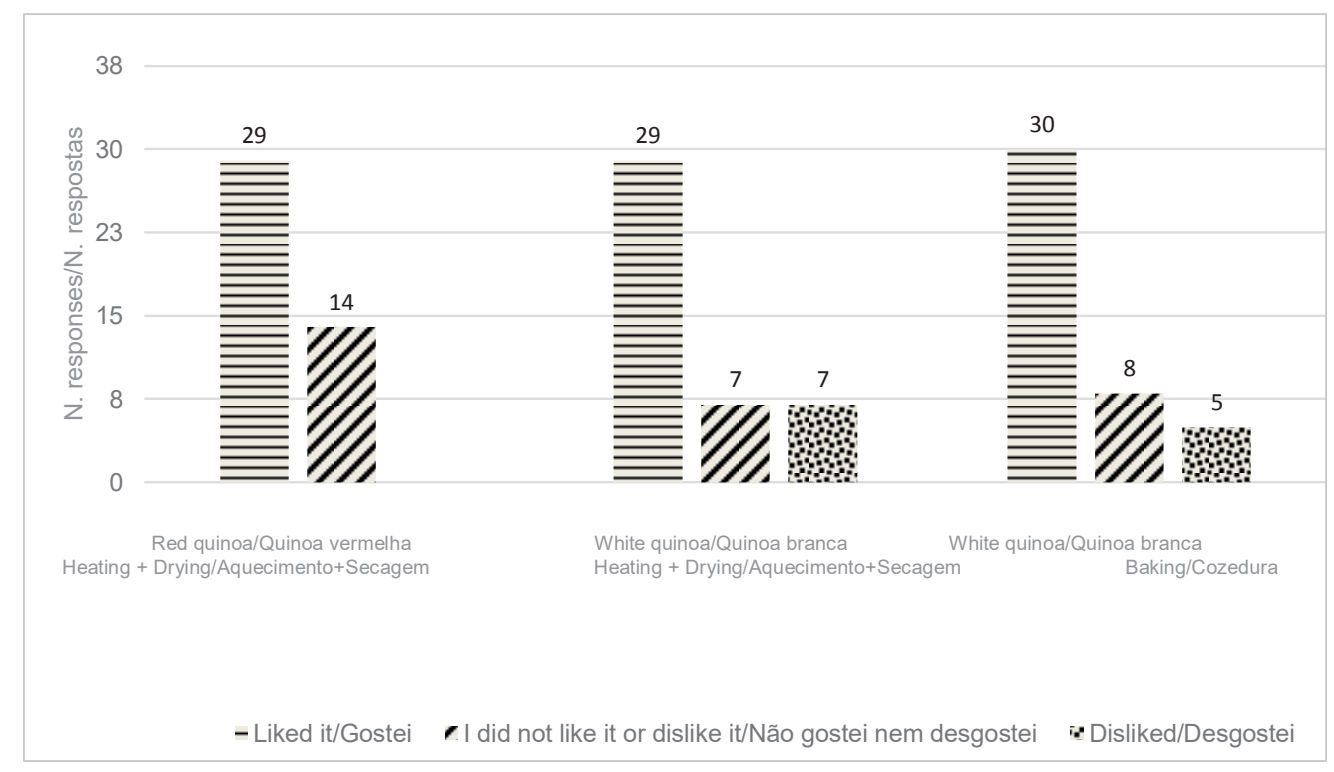

Figure 3/ Figura 3 - Results of the sensorial evaluation of the white and red quinoa bars processed at different conditions (only the scored levels of the scale are indicated)/ Resultados da avaliação sensorial de barras de quinoa branca e vermelha processadas em diferentes condições. Verde - gostei; Azul claro - não gostei nem desgostei; Azul escuro - desgostei (apenas são indicados os níveis da escala que tiveram respostas). 
The use of a new ingredient in food products may presents nutritional advantages when it is rich in biologically active compounds. However, the incorporation of that ingredient can impart some modifications on the food structure, reflected by texture and sensorial changes. Food texture is an important quality attribute which can be defined as a group of physical characteristics deriving from the structural elements that constitute the food product [16] (e.g. polysaccharides, proteins). These properties are sensorially detected, but some instrumental methods enable to determine food texture properties, with good correlation with sensory analysis tests. Considering the high costs associated to training a sensory panel, this can be advantageous. The texturometer (Figure 4) is composed by a dynamometer which provides mechanical energy to a probe that will contact the sample (at a constant rate) causing a deformation. The response of the material is recorded in force vs. time curves (Figure 5).

The bars texture was evaluated performing cutting tests (Figure 4) and firmness was calculated from the texturograms. White quinoa bars baked in the oven, the product preferred by the consumer panel, showed greater firmness $(21.8 \mathrm{~N} \pm 6.1 \mathrm{~N})$ when compared with the white quinoa bars heated at $70^{\circ} \mathrm{C}$ and dried at $70^{\circ} \mathrm{C}$ for $24 \mathrm{~h}(14.9 \mathrm{~N} \pm 5.5 \mathrm{~N})$. However, due to its higher firmness, it was not possible to analyse the bar samples with red quinoa prepared by heating and drying.

In respect to colour results (Table 2), all quinoa bars showed positive $a^{*}$ values, i.e. in the red domain, and positive $b^{*}$ values, correspondent to yellow tonality. The product which had higher sensory scores given by the consumer panel presented higher $a^{*}$ and $b^{*}$ values and also higher luminosity $\left(\mathrm{L}^{*}=34.7 \%\right.$; $\mathrm{a}^{*}=$ $9.4 ; b^{*}=16.7$ for white quinoa bars baked at $180^{\circ} \mathrm{C}$ ). Comparing the bars processed by heating and drying at $70^{\circ} \mathrm{C}$, with white or red quinoa as ingredient, it can be conclude that red quinoa contributes to higher a*, $b^{*}$ and $L^{*}$ values. However, red and yellow tonalities are more intense (superior $\mathrm{a}^{*}$ and $\mathrm{b}^{*}$ values) after the baking process at $180^{\circ} \mathrm{C}-25$ minutes, even when white quinoa is used, and these bars are lighter (superior L* value).
A incorporação de um novo ingrediente no alimento pode trazer vantagens nutricionais quando este é rico em compostos bioativos. No entanto, a incorporação desse ingrediente pode implicar a alteração da estrutura do material, refletindo-se em alterações sensoriais e de textura. A textura é um importante atributo da qualidade de um produto alimentar e pode ser definido como o grupo de características físicas que derivam dos elementos estruturais que constituem o alimento [16] (ex. polissacáridos, proteínas). Estas propriedades são avaliadas sensorialmente, mas alguns métodos instrumentais permitem determinar as propriedades de textura, tendo boa correlação com os testes sensoriais. Tendo em conta os elevados custos de treino e manutenção de um painel de provadores, o uso deste tipo de equipamento apresenta vantagens.

O texturómetro (Figura 4) é composto por um dinamómetro que fornece energia mecânica a uma sonda que contacta com a amostra (a uma velocidade constante), deformando-a. A resposta do material é registada em curvas de força vs. Tempo (Figura 5). A textura das barras de quinoa foi avaliada usado testes de corte (Figura 4), calculando o parâmetro firmeza a partir dos texturogramas obtidos. As barras de quinoa branca cozidas no forno, o produto preferido pelos consumidores, apresentou um valor mais alto de firmeza $(21,8 \mathrm{~N} \pm 6,1 \mathrm{~N})$ do que o das barras de quinoa branca produzidas por aquecimento a $70^{\circ} \mathrm{C}$ e secagem posterior a $70^{\circ} \mathrm{C}$ durante $24 \mathrm{~h}(14,8 \mathrm{~N} \pm 5,5 \mathrm{~N})$. Contudo, devido à sua elevada firmeza, não foi possível medir as barras de quinoa vermelha preparadas por aquecimento e secagem a $70^{\circ} \mathrm{C}$. No que respeita à cor (Tabela 2), todas as barras de quinoa apresentaram valores positivos de $\mathrm{a}^{*}$, correspondentes ao vermelho, e valores positivos de $b^{*}$, correspondentes à tonalidade amarela. $\mathrm{O}$ produto com melhor avaliação do painel apresentou maiores valores de $\mathrm{a}^{*} \mathrm{e}$ $b^{*}$ e também maior luminosidade $\left(\mathrm{L}^{*}=34,7 \% ; \mathrm{a}^{*}=9,4\right.$; $b^{*}=16,7$ para a barra de quinoa branca cozida a $180^{\circ} \mathrm{C}$ ). Comparando as barras processadas com aquecimento e secagem a $70^{\circ} \mathrm{C}$, com quinoa branca ou vermelha, conclui-se que a quinoa vermelha produz barras com valores mais elevados de $a^{*}, b^{*}$ e L*. Contudo, as tonalidades vermelha e amarela são mais intensas (valores superiores de $\left.\mathrm{a}^{*} \mathrm{e} \mathrm{b}^{*}\right)$ quando as barras são produzidas por cozedura a $180^{\circ} \mathrm{C}-25 \mathrm{~min}$, mesmo quando se usa quinoa branca, barras estas que também são mais claras (valor superior de $\mathrm{L}^{*}$ ). 


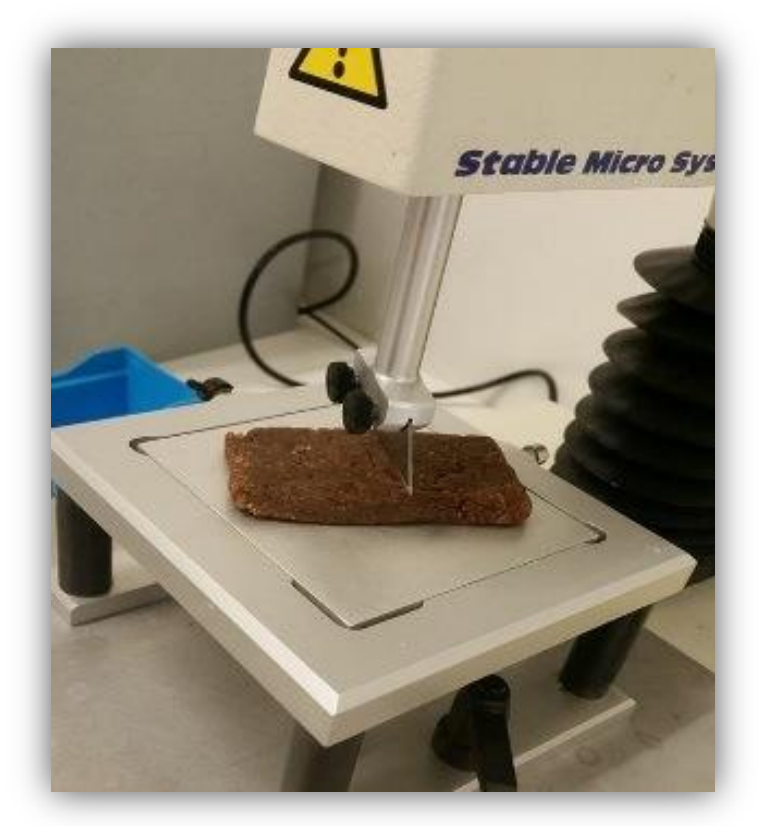

Figure 4/ Figura 4 - Instrumental analysis of texture of red quinoa bar, using a texturometer attached with a Craft Knife Blade probe. Avaliação instrumental da textura de uma barra de quinoa vermelha, usando o texturómetro com uma sonda de corte.

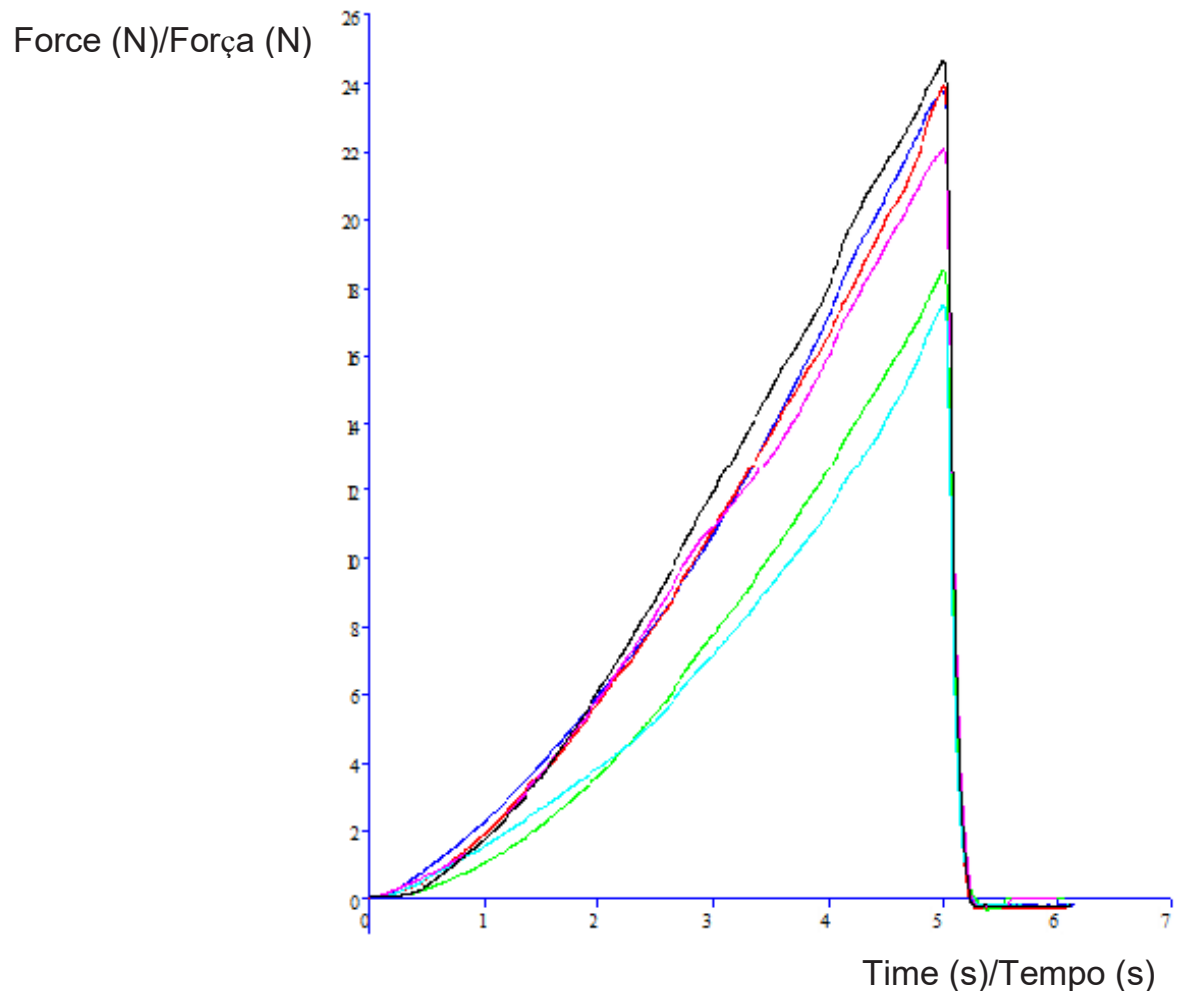

Figure 5/ Figura 5 - Examples of texturograms obtained from cutting tests.

Firmness is recorded as the maximum peak of force.

Exemplos de texturogramas obtidos nos testes de corte. A firmeza corresponde ao pico máximo da força. 


\section{Conclusion}

This work suggests that quinoa is an interesting functional ingredient to develop new cereal bars as an alternative to the conventional commercial products, with desirable physical and sensory proprieties. The nutritional evaluation should be made in future studies.

Although there is no statistical significance in the differences on evaluation results between the three bars, the processing conditions tested in this study are promising for the production of those white or red quinoa bars in future studies.

\section{Conflict of interest}

The authors declare that there is no financial or personal relationship that can be understood as representing a potential conflict of interest.

\section{Conclusão}

Este trabalho sugere que a quinoa é um ingrediente funcional interessante para o desenvolvimento de novas barras de cereais como uma alternativa aos produtos comerciais convencionais, com propriedades físicas e sensoriais desejáveis. Em estudos futuros, a avaliação nutricional deve ser feita. Embora não exista significado estatistico nos resultados da avaliação entre as três barras, as condições de processamento testadas neste estudo são promissoras para a produção destas barras de quinoa branca ou vermelha, em futuros estudos.

\section{Conflito de interesses}

Os autores declaram não existirem quaisquer relações de natureza financeira ou pessoal que possam ser entendidas ou representarem um potencial conflito de interesses. 


\section{References/ Referências}

[1] Conto L, Desenvolvimento de barra de cereais formulada com farinha de pinhão, $4^{\circ}$ Seminário de Pesquisa, Extensão e Inovação do IFSC, 2014

[2] Pinedo A, Salles Z, Beserra N, Zuniga A., Coelho A, Pinedo R, Desenvolvimento de barra de cereais à base de farinha de amêndoa de babaçu, Revista Brasileira de Produtos Agroindustriais 2013, 15 (4), 405-411.

[3] Navruz-Varli S, Sanlier N, Nutritional and health benefits of quinoa (Chenopodium quinoa Willd.), Journal of Cereal Science 2016, 69, 371-376.

[4] Vilcacundo R, Hernández-Ledesma B, Nutritional and biological value of quinoa (Chenopodium quinoa Willd.), Current Opinion in Food Science 2017, $14,1-6$.

[5] Nowak V, Du J, Charrondiere R, Assessment of the nutritional composition of quinoa (Chenopodium quinoa Willd.), Food Chemistry 2016, 193 , 47-54.

[6] Escribano J, Cabanes J, Jiménez-Atiénjar M, Ibanez-Tremolada M, Gómez-Pando LR, Garcia-Carmona F, Gandia-Herrero F, Characterization of betalains, saponins and antioxidant power in differently colored quinoa (Chenopodium quinoa) varieties. Food Chemistry 2017, 234, $285-294$.

[7] Bick MA, Fogaca AO, Storck CR, Biscoitos com diferentes concentrações de farinha de quinoa em substituição parcial à farinha de trigo, Braz J Food Technol 2014, 17 (2),121-129.

[8] Stikic R, Djordje G, Mirjana D, Vucelic-Radovic B, Jovanovic Z, Milojkovic-Opsenica D, Jacobsen S, Milovanovic M, Agronomic and nutritional evaluation of quinoa seeds (Chenopodium quinoa Wild.) as an ingredient in bread formulations, Journal of Cereal Science 2012, 55, 132-138.

[9] GutkoskI L, Bonamigo J, Teixeira, Freitas D, Pedo I, Desenvolvimento de barras de cereais à base de aveia com alto teor de fibra alimentar, Ciênc. Tecnol. Aliment. 2007, 27 (2), 355-363.

[10] Freitas J, Naves M, Composição química de nozes e sementes comestíveis e sua relação com a nutrição e saúde, Rev. Nutr. 2010,23 (2), $269-279$.

[11] Lima A, Nebra S, Queiroz M, Aspetos científicos e tecnológicos da banana, Revista Brasileira de Produtos Agroindustriais 2000, 2 (1), 87-101.

[12] Fradinho P, Nunes MC, Raymundo A, Developing consumer acceptable biscuits enriched with Psyllium fibre, Journal of Food Science and Technology 2015, 52 (8), 4830-4840.

[13] Raymundo A, Fradinho P, Nunes MC, Effect of Psyllium fiber content on the textural and rheological characteristics of biscuit and biscuit dough, Bioactive Carbohydrates and Dietary Fibre 2014, 3, 96-105.

[14] Fradique M, Batista AP, Nunes MC, Gouveia L, Bandarra NM, Raymundo A, Incorporation of Chlorella vulgaris and Spirulina maxima biomass in pasta products. Part I: Preparation and evaluation, Journal of the Science of Food and Agriculture 2010, 90,1656-1664.

[15] CIE - Comission Internationale de 1'Eclairage, Publication n. ${ }^{\circ} 15$ (E-1.3.1) 1971, Supplement 2, Viena, 1978.

[16] Bourne MC, Food Texture and Viscosity: Concept and Measurement, Academic Press, London, 2002. 